Article

\title{
Adsorption of Arsenic and Lead onto Stone Powder and Chitosan-Coated Stone Powder
}

\author{
Kyungho Jung ${ }^{1}$, Sanghwa Oh ${ }^{1} * \mathbb{1}$, Hun Bak ${ }^{2}$, Gun-Ho Song ${ }^{1}$ and Hong-Tae Kim ${ }^{2}$ \\ 1 School of Architectural, Civil, Environmental, and Energy Engineering, Kyungpook National University, \\ Daegu 41566, Korea; chilbo4518@hanmail.net (K.J.); sgh0799@hanmail.net (G.-H.S.) \\ 2 Department of Civil Engineering, Kyungpook National University, Daegu 41566, Korea; \\ hee08160@naver.com (H.B.); htkim@knu.ac.kr (H.-T.K.) \\ * Correspondence: shoh@knu.ac.kr; Tel.: +82-53-950-5609
}

Received: 20 August 2019; Accepted: 2 September 2019; Published: 5 September 2019

check for updates

\begin{abstract}
Stone powder (SP) produced from masonry mills has been treated as a specific waste and rarely used for environmental purposes. In this study, we tested its potential as an adsorbent to remove arsenic $(\mathrm{As})$ and lead $(\mathrm{Pb})$ from water. The single-solute sorption isotherms for $\mathrm{As}(\mathrm{V})$ and $\mathrm{Pb}$ (II) onto SP and chitosan-coated SP (CSP) were investigated. Several sorption models, such as the Langmuir, Freundlich, and Dubinin-Radushkevich (DR) models, were used to analyze the adsorption features. The results demonstrated that $\mathrm{As}$ and $\mathrm{Pb}$ were successfully adsorbed onto SP and CSP, indicating that SP and CSP had potential as adsorbents of As and $\mathrm{Pb}$. The maximum adsorption capacities of SP and CSP for Pb were 22.8 and 54.5 times higher than those for As, respectively. Chitosan coating increased the adsorption potential in $\mathrm{Pb}$ adsorption by $5 \%$ but decreased it in $\mathrm{As}$ adsorption. The adsorption potential also depended on the $\mathrm{pH}$ and temperature. The adsorption amount of As increased with $\mathrm{pH}$ but that of $\mathrm{Pb}$ decreased as $\mathrm{pH}$ increased. In addition, the $\ln b$ in the Langmuir model increased with $1 / \mathrm{T}(\mathrm{K})$, indicating that the adsorption of As and $\mathrm{Pb}$ occurred exothermically and spontaneously.
\end{abstract}

Keywords: arsenic; lead; adsorption; stone powder; chitosan-coated stone powder

\section{Introduction}

Given their frequency, toxicity, and potential for human exposure, arsenic (As) and lead $(\mathrm{Pb})$ are the most prioritized substances by the Agency for Toxic Substances and Disease Registry (ATSDR) in the USA. One of their main exposure pathways is groundwater, one of the most important water supplies in the world. Therefore, groundwater pollution with $\mathrm{As}$ and $\mathrm{Pb}$ has been a great threat to the use of drinking water in countries worldwide such as China, Bangladesh, the USA, Nepal, Vietnam, Mexico, Argentina, Spain, Japan, India, and Korea [1-3]. Many people who have used groundwater as drinking water have been dying or suffering from diseases. In particular, long-term use of Asor Pb-contaminated groundwater can cause various kinds of cancers [4]. Despite these problems, groundwater is still a major source of drinking water [5]. Therefore, various technologies to remove As and $\mathrm{Pb}$ from groundwater chiefly and effectively have been researched.

Stone powder (SP) is mainly made of granite in Korea and produced from masonry mills or in the process of producing crushed sand. SP generally consists of $\mathrm{SiO}_{2}$ and $\mathrm{Al}_{2} \mathrm{O}_{3}$ and is similar to Class $\mathrm{F}$ fly ash $[6,7]$. When mixed with water, SP has high strength, and thus, it can be recycled as a geopolymer or an admixture of concrete [7]. However, SP has been classified as a specific waste in Korea, and its huge production has been causing great environmental concern because of the potential of surface water and groundwater contamination, the relative lack of reuse or recycling, and its illegal disposal. In addition, there has been very little research on the environmental use of SP. Al-Jabari et al. [8] successfully used 
stone cutting solid waste to adsorb organic materials in dairy wastewater. In this study, small amounts of iron powder were produced during the processing of stones due to the wear of saws, and the iron powder could be separated using a magnet. This iron powder was expected to be a good adsorbent for arsenic and heavy metals.

Chitosan-based adsorbents are receiving great attention due to their eco-friendly adsorption properties. Chitosan is very effective in adsorbing metals due to its high amino and carboxyl functional group content [9], and coating the surface of SP with chitosan can enhance SP's adsorption ability. Therefore, many researchers have attempted to coat the surface of adsorbents with chitosan to provide high adsorption capacities [9-11]. Qi and $\mathrm{Xu}$ [10] investigated the applicability of chitosan nanoparticles to lead sorption and found they could sorb $\mathrm{Pb}$ ions effectively with $398 \mathrm{mg} / \mathrm{g}$ of the maximum sorption capacity of $\mathrm{Pb}$. Gupta et al. [11] presented that chitosan-coated sand (CCS) had a high arsenic adsorption capacity $(23 \mathrm{mg} / \mathrm{g})$ and was successfully applied for the removal of total inorganic arsenic $(<10 \mu \mathrm{g} / \mathrm{L})$ from arsenic-contaminated groundwater. In addition, we expected that chitosan could be used as a stone and iron powder linker due to its high adhesion feature [12]. Although chitosan is considered a good adsorbent and cross-linker, the use of chitosan alone would be expensive [11]. Coating the surface of inexpensive waste materials, such as SP with chitosan, would be one of the best ways to reduce the cost.

In this study, chitosan-coated stone powder (CSP) and stone powder (SP) were prepared, and their adsorption features were evaluated for the removal of $\mathrm{As}$ and $\mathrm{Pb}$ at various $\mathrm{pH}$ values. Several adsorption models (the Freundlich, Langmuir, and Dubinin-Radushkevich (DR) models) were used to fit the experimental data to explain the adsorption features. In addition, the temperature effect on adsorption was also investigated.

\section{Materials and Methods}

\subsection{Materials}

SP, granite sludge consisting mainly of $\mathrm{SiO}_{2}$ and $\mathrm{Al}_{2} \mathrm{O}_{3}$, was obtained from a masonry mill in Yeongcheon, Korea. The collected SP samples were air-dried for more than 5 days and sieved through a $75 \mu \mathrm{m}$ mesh (sieve \#200), mixed, and stored in an airtight plastic container before use. Sodium arsenate dibasic heptahydrate $\left(\mathrm{Na}_{2} \mathrm{HAsO}_{4},>99.0 \%\right)$ was purchased from Wako, Japan. Lead nitrate $\left(\mathrm{Pb}\left(\mathrm{NO}_{3}\right)_{2}\right.$, $>99.0 \%$ ) was purchased from Duksan Co., Korea. Chitosan produced from crab shell was purchased from Daejung Co., Korea. Acetic acid $\left(\mathrm{CH}_{3} \mathrm{COOH},>98.0 \%\right)$ used for dissolving chitosan was also purchased from Duksan Co., Korea. Hydrochloric acid ( $\mathrm{HCl}, 35 \%-37 \%)$ was purchased from Duksan Co., Korea. MES (2-( $\mathrm{N}$-morpholino)ethanesulfonic acid, $>98.0 \%)$ and sodium bicarbonate (NaHCO, $>99.0 \%$ ), used as a pH buffer, were also purchased from Daejung Co., Korea.

\subsection{Preparation of CSP}

In order to enhance the field application of SP, it was coated with the chitosan through modification of Gupta's method [12]. Briefly, SP was washed twice with deionized (DI) water (Milli-Q, $18 \mathrm{M} \Omega-\mathrm{cm}$ ) and $1 \mathrm{M} \mathrm{HCl}$ to remove the adsorbed metal ions and dried at $90{ }^{\circ} \mathrm{C}$ for $20 \mathrm{~h}$ to activate the salts.

For the chitosan coating process, chitosan was dissolved in $0.05 \mathrm{M}$ acetic acid to make the final concentration of $0.5 \%$ by weight. The activated SP was mixed with the chitosan solution. The mixture was stirred overnight, washed with DI water, and then dried at room temperature before use.

\subsection{Physicochemical Analysis of SP and CSP}

The specific surface areas of SP and CSP were measured from $\mathrm{N}_{2}$ adsorption isotherms by the Brunauer-Emmett-Teller (BET) method (BET Quantachrome, Autosorb-iQ, Florida, FL, USA). The X-ray diffraction (XRD) of SP and CSP was carried out using an X-ray diffractometer (D/Max-2500, Rigaku, Japan). A field emission scanning electron microscope (FE-SEM, SU8220, Hitachi, Japan) was applied to observe the morphology of the adsorbents, and an energy dispersive $\mathrm{X}$-ray spectroscope 
(EDS, Horiba E-MAX EDS detector, Japan) was also used to characterize the chemical compositions. The BET, FE-SEM, and EDS analyses were conducted at the Instrumental Analysis Center of Kyungpook National University, Korea. The X-ray fluorescence (XRF) analyses were conducted using a wavelength dispersive X-ray fluorescence spectrometer (WD-XRF) at the Korea Basic Science Institute (Daegu). The point of zero charge (PZC) was determined by a batch method [13].

\subsection{Adsorption Experiment}

Adsorption isotherms for As and $\mathrm{Pb}$ were determined in SP and CSP to ascertain the effect of chitosan coating on $\mathrm{As}$ and $\mathrm{Pb}$ adsorption features. The standard batch technique was used in this study. Briefly, As and $\mathrm{Pb}$ solutions with 0.001 to $1.21 \mathrm{mmol} / \mathrm{L}$ and 200 to $2000 \mathrm{mg} / \mathrm{L}$, respectively, were prepared. Approximately $1 \mathrm{~g}$, on a dry weight basis, of SP or CSP was added to $50 \mathrm{~mL}$ of artificially As- or Pb-contaminated water in screw-cap conical tubes. The tubes were capped tightly, shaken at $200 \mathrm{rpm}$ for $24 \mathrm{~h}$ in an orbital shaker. Preliminary equilibrium time experiments showed less than $6 \mathrm{~h}$ for both $\mathrm{As}$ and $\mathrm{Pb}$ adsorptions (data not shown). After mixing, the tubes were collected and centrifuged at $2000 \mathrm{rpm}$ for $10 \mathrm{~min}$. The supernatant was filtrated through a $0.2 \mu \mathrm{m}$ membrane filter (cellulose nitrate membrane, Whatman). The $\mathrm{As}$ and $\mathrm{Pb}$ concentrations in the aqueous phases were analyzed using a inductively coupled plasma (ICP, Optima 2100 DV, PerkinElmer, Sweden).

An experiment on the effect of $\mathrm{pH}$ on the adsorption of $\mathrm{As}$ and $\mathrm{Pb}$ was also conducted by adjusting the $\mathrm{pH}$ of the metal solutions to 4, 7, and 9 for As adsorption, and 3, 4.5, and 7 for Pb adsorption using MES and bicarbonate buffers. The $\mathrm{pH}$ buffers used in this study did not affect $\mathrm{As}$ and $\mathrm{Pb}$ adsorption $[14,15]$. The adsorption step for the $\mathrm{pH}$ effect experiment was the same as that for the adsorption isotherm experiment. To investigate the effect of temperature on adsorption, the adsorption isotherm experiments were conducted at three different temperatures $\left(20^{\circ} \mathrm{C}, 30^{\circ} \mathrm{C}\right.$, and $\left.40{ }^{\circ} \mathrm{C}\right)$. All experiments were conducted in duplicate.

The adsorbed amount, $q(\mathrm{mmol} / \mathrm{kg})$, was calculated using Equation (1):

$$
q=\frac{\left(C_{0}-C\right) V}{W}
$$

where $C_{0}$ is the initial solute concentration $(\mathrm{mmol} / \mathrm{L}), C$ is the residual solute concentration $(\mathrm{mmol} / \mathrm{L})$, $V$ is the sample volume (L), and $W$ is the weight of the adsorbent, such as SP or CSP $\left(\times 10^{-3} \mathrm{~kg}\right)$.

\subsection{Isotherm Model}

The adsorbed amount $(q)$ against the equilibrium concentration of solute in solution $(C)$ was plotted and evaluated with several adsorption isotherm models such as the Freundlich, Langmuir, and DR models.

The Freundlich model was developed to describe monolayer gas adsorption on heterogeneous solids, and it provides a basic equation for understanding nonlinear adsorption [16]. The Freundlich equation can be expressed as:

$$
q=K_{F} C^{N},
$$

where $K_{F}$ is the adsorption capacity, and the exponent $\left[(\mathrm{mmol} / \mathrm{kg}) /(\mathrm{mmol} / \mathrm{L})^{N}\right], N$, characterizes the energy distribution of the adsorption sites (unitless). $N<1$ indicates nonlinear adsorption, where the marginal adsorption energy decreases with increasing surface concentration [16].

The Langmuir model was formulated for monolayer adsorption on homogeneous surfaces. The equation can be expressed as:

$$
q=\frac{q_{m L} b C}{1+b C^{\prime}}
$$

where $q_{m L}$ is the maximum adsorption capacity $(\mathrm{mmol} / \mathrm{kg})$, and $b$ is characterized as constant adsorption energy $(\mathrm{L} / \mathrm{mmol})$. 
The DR model is generally applied to express the adsorption mechanism with a Gaussian energy distribution on heterogeneous surfaces $[17,18]$, and therefore, it can distinguish between physical and chemical adsorption characteristics [19]:

$$
q=q_{m D} \exp \left(-\beta \varepsilon^{2}\right)=q_{m D} \exp \left[-\beta\left(R T \ln \left(1+\frac{1}{C}\right)\right)^{2}\right],
$$

where $q_{m D}$ is the theoretical saturation capacity $(\mathrm{mmol} / \mathrm{kg}), \beta$ is characterized as the mean free energy of adsorption per mole of sorbate $\left(\mathrm{mol}^{2} / \mathrm{J}^{2}\right)$, and $\varepsilon$ is the Polanyi potential:

$$
\varepsilon=R T \ln \left(1+\frac{1}{C}\right)
$$

where $R$ is the gas constant $(8.314 \mathrm{~J} / \mathrm{mol} \cdot \mathrm{K})$, and $T(\mathrm{~K})$ is the absolute temperature. The mean free energy $E(\mathrm{~J} / \mathrm{mol})$ can be calculated from $\beta$ :

$$
E=\frac{1}{\sqrt{2 \beta}}
$$

\subsection{Thermodynamic Analysis}

Thermodynamic analyses of the adsorption were conducted to estimate whether the reaction was spontaneous or not. The Langmuir parameter, $b$, was used as the thermodynamic parameter for Gibb's free energy change, $\Delta G^{\circ}(\mathrm{kJ} / \mathrm{mol})$, in the adsorption process. The change in Gibb's free energy is a negative value if the reaction occurs spontaneously. The changes in enthalpy, $\Delta H^{\circ}(\mathrm{kJ} / \mathrm{mol})$, and entropy, $\Delta S^{\circ}(\mathrm{J} / \mathrm{mol} / \mathrm{K})$, are calculated using [20,21]:

$$
\begin{gathered}
\Delta G^{0}=-R T \ln b \\
\Delta G^{0}=\Delta H^{0}-T \Delta S^{0} .
\end{gathered}
$$

These equations can be expressed as:

$$
\ln b=\frac{\Delta S^{0}}{R}-\frac{\Delta H^{0}}{R T}
$$

As shown in Equation (9), a plot of $\ln b$ vs. 1/T can give other thermodynamic parameters, such as the change of enthalpy and entropy [21].

\section{Results}

\subsection{SP and CSP Characteristics}

The specific area, pore volume, pore size, and $\mathrm{pH}$ values of SP and CSP are summarized in Table 1. The surface areas of SP and CSP were 2.78 and $2.64 \mathrm{~m}^{2} / \mathrm{g}$, respectively. The pore volume and pore size were $0.017 \mathrm{~cm}^{3} / \mathrm{g}$ and $24.83 \mathrm{~nm}$ for SP, and $0.015 \mathrm{~cm}^{3} / \mathrm{g}$ and $22.77 \mathrm{~nm}$ for CSP, respectively, indicating that $\mathrm{SP}$ has a relatively larger pore volume and pore size due to the thin chitosan-coated layer. The results of the XRD analyses of SP and CSP are shown in Figure 1. The XRD patterns of SP and CSP showed that SP contained a series of quartz $\left(\mathrm{SiO}_{2}\right)$ with the main peak at $2 \theta=26.6^{\circ}$ [22]. The results of the XRF analyses for SP and CSP are summarized in Table 2. The XRF results also revealed that $\mathrm{SiO}_{2}$ was the main component of SP and CSP (65.69\% and 66.11\%, respectively); $\mathrm{Al}_{2} \mathrm{O}_{3}$, $\mathrm{CaO}$, and $\mathrm{Fe}_{2} \mathrm{O}_{3}$ were also mainly detected. 

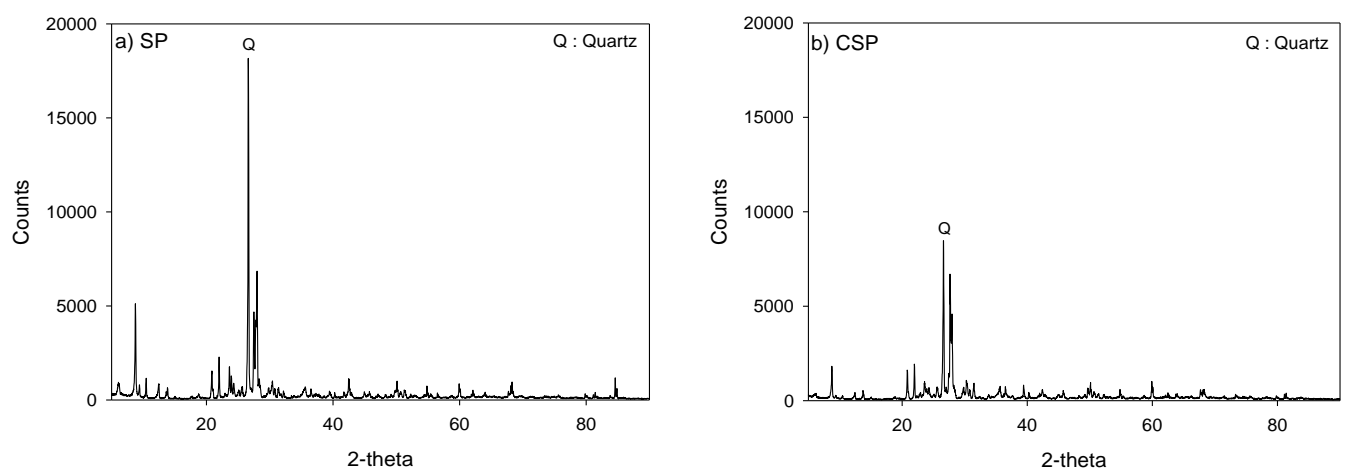

Figure 1. Results of XRD analyses of (a) stone powder (SP) and (b) chitosan-coated SP (CSP).

Table 1. Surface area, pore volume, pore size, and $\mathrm{pH}$ of SP and CSP.

\begin{tabular}{ccc}
\hline & SP & CSP \\
\hline BET surface area $\left(\mathrm{m}^{2} / \mathrm{g}\right)$ & 2.78 & 2.64 \\
Pore volume $\left(\mathrm{cm}^{3} / \mathrm{g}\right)$ & 0.017 & 0.015 \\
Pore size $(\mathrm{nm})$ & 24.83 & 22.77 \\
$\mathrm{pH}$ & 4.7 & 4.9 \\
\hline
\end{tabular}

Table 2. Results of the X-ray fluorescence (XRF) analyses for SP and CSP.

\begin{tabular}{ccc}
\hline Component & SP & CSP \\
\hline $\mathrm{Al}_{2} \mathrm{O}_{3}$ & 16.22 & 16.19 \\
$\mathrm{CaO}$ & 4.57 & 4.60 \\
$\mathrm{Fe}_{2} \mathrm{O}_{3}$ & 4.03 & 3.49 \\
$\mathrm{~K}_{2} \mathrm{O}$ & 2.69 & 2.61 \\
$\mathrm{MgO}$ & 2.50 & 2.34 \\
$\mathrm{Na}_{2} \mathrm{O}$ & 2.94 & 2.98 \\
$\mathrm{SiO}_{2}$ & 65.69 & 66.11 \\
L.O.I. & 0.74 & 1.11 \\
\hline
\end{tabular}

Figure 2 shows the surface morphologies (SEM images) and the EDS X-ray microanalyses of SP (a) and CSP (b). The SEM images show that the difference in the surface morphologies of SP and CSP was not significant. The EDS analyses were conducted on several particles, and the results showed that $\mathrm{Si}, \mathrm{Mg}, \mathrm{O}, \mathrm{Al}$, and Fe were prominent elements for both SP and CSP.
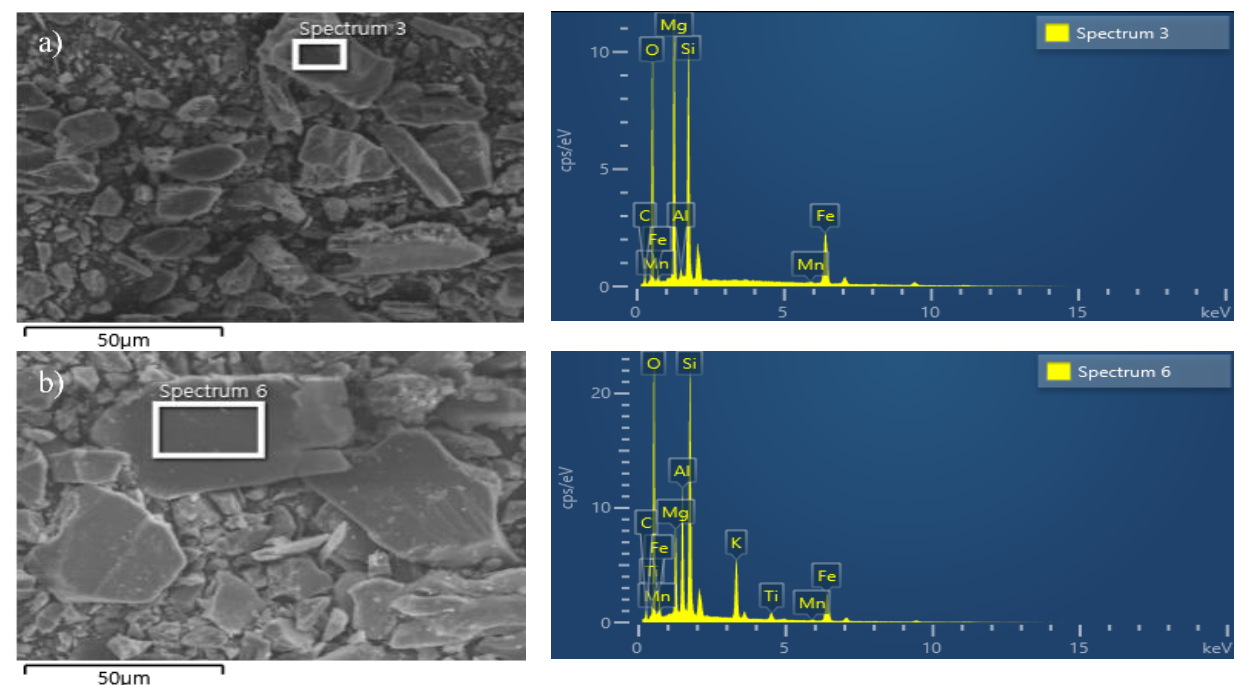

Figure 2. SEM images and EDS analyses for (a) SP and (b) CSP. 
Figure 3 elucidates a point of zero salt effect (PZSE) as the PZC in SP and CSP. The PZSE is the $\mathrm{pH}$ value at the crossover point of potentiometric titration curves obtained at different ionic strengths $[13,23]$. The results showed that the PZSE of SP (8.25) was higher than that of CSP (4.5), perhaps because the SP surface was coated with chitosan dissolved in acetic acid.
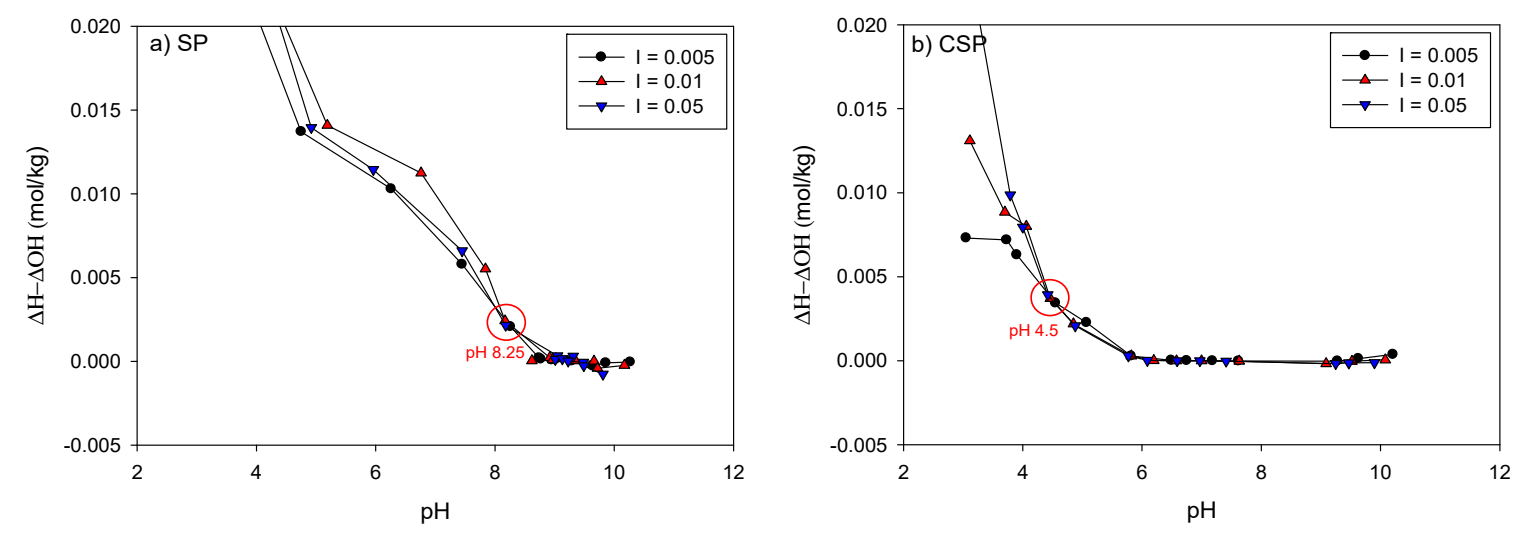

Figure 3. The point of zero charge (PZC) for (a) SP and (b) CSP.

\subsection{As and $\mathrm{Pb}$ Adsorption onto SP and CSP}

The solution speciations of As and $\mathrm{Pb}$ were calculated using Visual MINTEQ (Version 3.1, Sweden), and they are shown in Figure 4. $\mathrm{H}_{2} \mathrm{AsO}_{4}{ }^{-}$was the dominant As species at a $\mathrm{pH}$ between 3 and 6, and the dominant $\mathrm{Pb}^{2+}$ species at a $\mathrm{pH}$ below $7 . \mathrm{PbOH}^{+}$and $\mathrm{Pb}_{3}(\mathrm{OH})_{4}{ }^{+2}$ were dominant at a $\mathrm{pH}$ of 7 to 8 and 8 to 10 , respectively. Therefore, $\mathrm{H}_{2} \mathrm{AsO}_{4}{ }^{-}$and $\mathrm{Pb}^{2+}$ ions were dominant in solution at $\mathrm{pH} 4$ to 4.5, $\mathrm{HAsO}_{4}{ }^{-2}$ and $\mathrm{Pb}^{2+} / \mathrm{PbOH}^{+}$were dominant at $\mathrm{pH}$ 7, and $\mathrm{HAsO}_{4}{ }^{-2}$ and $\mathrm{Pb}_{3}\left(\mathrm{OH}_{4}\right)^{+2}$ were dominant at $\mathrm{pH} 9$, as shown in Figure 4. At a $\mathrm{pH}$ above $11, \mathrm{~Pb}(\mathrm{OH})_{3}{ }^{-}$was dominant.
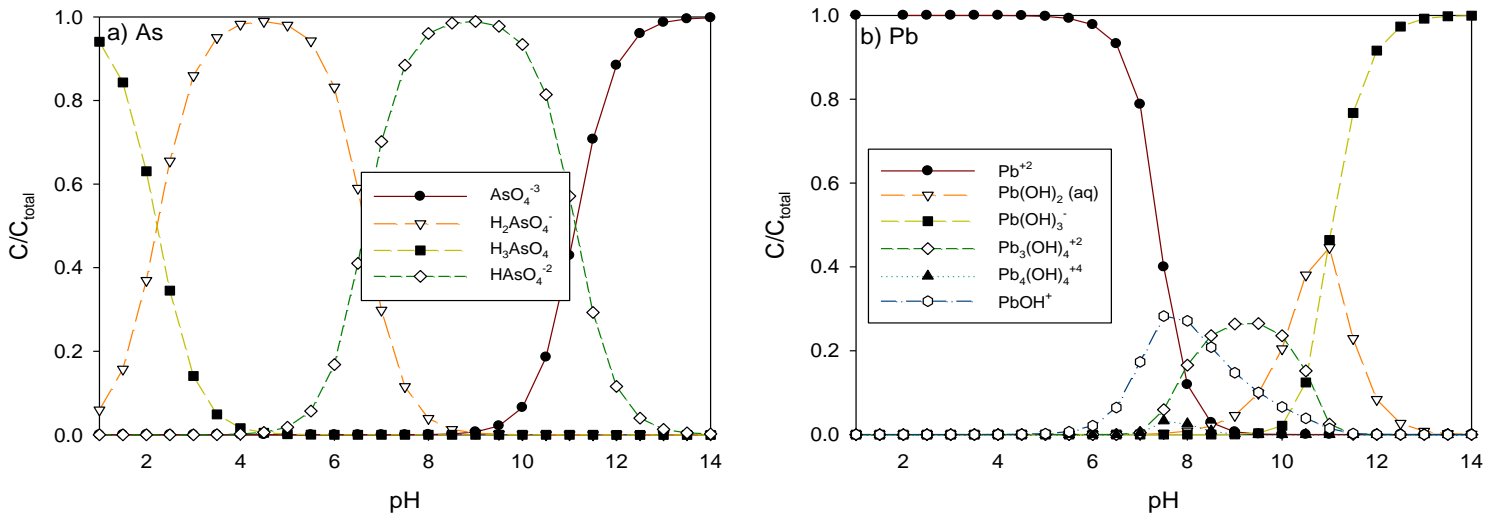

Figure 4. Distribution of (a) As and (b) $\mathrm{Pb}$ compounds as a function of $\mathrm{pH}$ predicted by Visual MINTEQ 3.1 software.

Figure 5 shows the adsorption isotherm patterns of $\mathrm{As}$ and $\mathrm{Pb}$ onto SP and CSP at three different pH conditions: 4, 7, and 9 for As adsorption, and 3, 4.5, and 7 for Pb adsorption. The isotherm model parameters for the Freundlich, Langmuir, and DR models are summarized in Table 3 (for As) and Table 4 (for $\mathrm{Pb}$ ). All adsorption patterns showed nonlinear L-type adsorption, indicating that strong interactions between adsorbate (As or Pb) and adsorbent (SP or CSP) occurred [15]. As shown in Table 3, all models had a similar range of the coefficient of determination $\left(\mathrm{R}^{2}\right)$ for each of the $\mathrm{pH}$ values. The $\mathrm{R}^{2}$ values were in the range of 0.762 to 0.900 for SP, and 0.611 to 0.942 for CSP for all models. Table 4 shows that the $\mathrm{R}^{2}$ values of the isotherm models for SP (0.678 to 0.928) were higher than those for CSP (0.569 to 0.816). The Freundlich and Langmuir models showed a better fit than the DR model. 
For estimating the effect of chitosan coating on $\mathrm{As}$ and $\mathrm{Pb}$ adsorption, the adsorption results of As and $\mathrm{Pb}$ were compared at the same $\mathrm{pH}$. A comparison of Tables 3 and 4 shows that $\mathrm{Pb}$ is more attracted for adsorption onto SP and CSP than As. The amount of As adsorbed on SP was higher than that on CSP at the same pHs, whereas the amount of $\mathrm{Pb}$ adsorbed on CSP was higher than that on SP, as shown in Figure 5.

For example, at $\mathrm{pH} 4$, the maximum amount $\left(q_{\mathrm{mL}}\right)$ of As adsorbed onto SP $(1.838 \mathrm{mmol} / \mathrm{kg})$ was higher than that onto CSP $(0.957 \mathrm{mmol} / \mathrm{kg})$, whereas the maximum amount of $\mathrm{Pb}$ adsorbed onto SP $(41.88 \mathrm{mmol} / \mathrm{kg})$ was less than that onto CSP $(52.18 \mathrm{mmol} / \mathrm{kg})$ at $\mathrm{pH} 4.5$. This indicates that the chitosan coating decreased the sorption capability of SP for As but increased it for Pb. The chitosan was known as a good adsorbent for As, but in this study, the chitosan coating had a negative effect on adsorption affinity of As. Anto and Annadurai [24] also studied the effect of concentration of the chitosan nanoparticle from $0.5 \%$ to $1.2 \%$ on As adsorption capacity onto chitosan nanoparticle immobilized into sodium alginate and found the decreasing pattern of As adsorption capacity from $21.7 \mathrm{mg} / \mathrm{g}$ at $0.5 \%$ to $16.7 \mathrm{mg} / \mathrm{g}$ at $1.2 \%$, except $23.7 \mathrm{mg} / \mathrm{g}$ at $1.0 \%$. In this study, although the $\mathrm{pH}$ was adjusted by $\mathrm{pH}$ buffer solutions, the final $\mathrm{pH}$ value increased to the range of 4.5 to 5.6 during adsorption. The final $\mathrm{pH}$ was higher than the PZC value of CSP (4.5), which indicates a negative charge of the CSP surface. In addition, As compounds also exist with a negative charge as $\mathrm{pH}$ increases, which produces the repulsion forces between As compounds and SP or CSP [12]. On the other hand, because $\mathrm{Pb}$ is positively charged, it is easily adsorbed to negatively charged SP and CSP particles $[25,26]$. The maximum adsorption amount of $\mathrm{Pb}$ at a $\mathrm{pH}$ of 4.5 was about 20 to 50 times higher than that of As at $\mathrm{pH} 4$, according to $q_{\mathrm{mL}}$ and $q_{\mathrm{mD}}$. $K_{\mathrm{F}}$ values in the Freundlich model for As adsorption were lower than those for $\mathrm{Pb}$ adsorption due to the higher adsorption affinity of $\mathrm{Pb}$. The $N$ values in the Freundlich model were in the range of 0.248 to 0.738 for As and 0.221 to 0.431 for $\mathrm{Pb}$, indicating that $\mathrm{As}$ and $\mathrm{Pb}$ adsorption was nonlinear and favorable [27].
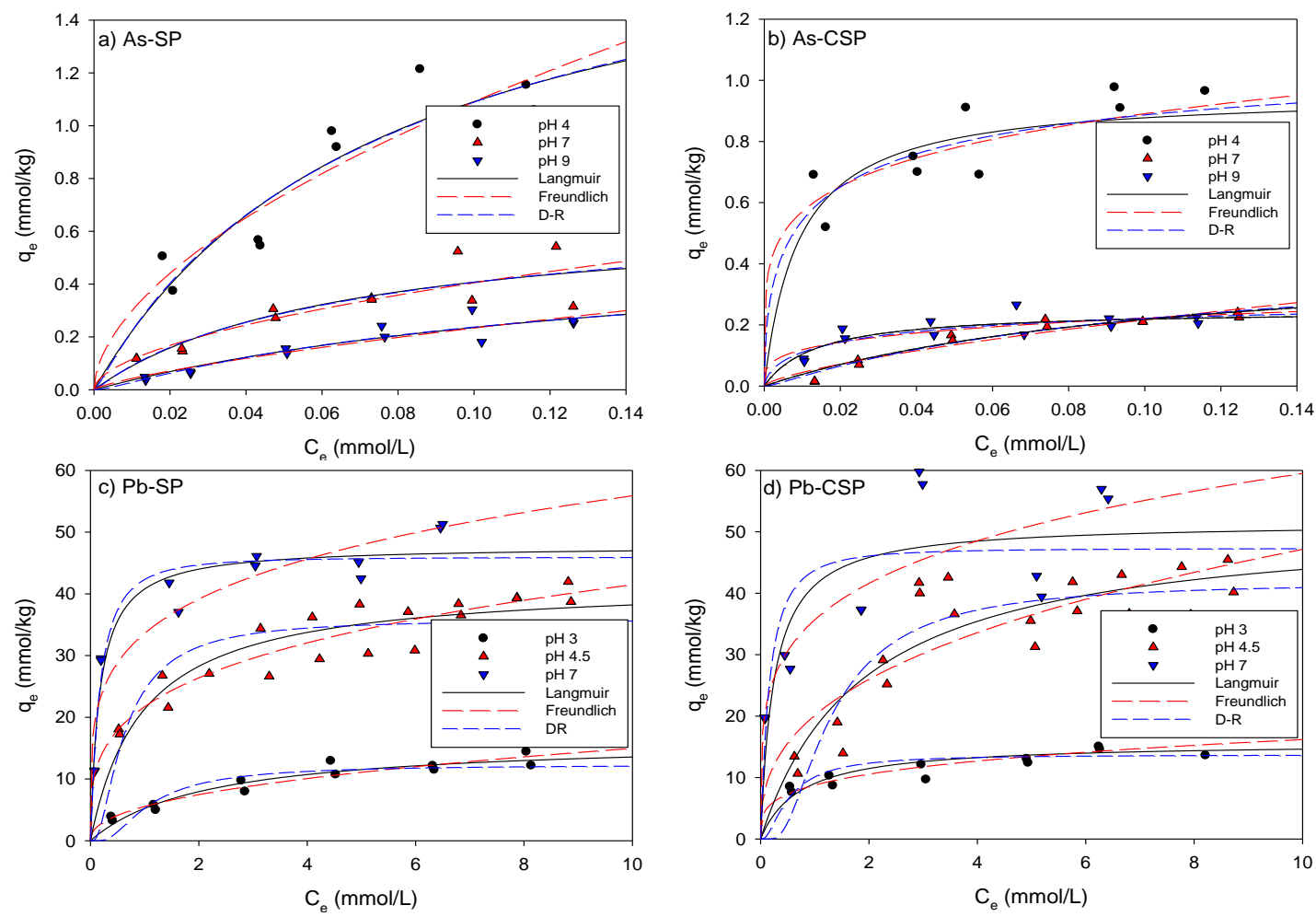

Figure 5. Effect of $\mathrm{pH}$ on (a,b) As and (c,d) Pb adsorption onto (a,c) SP and (b,d) CSP. 
Table 3. Isotherm model parameters for As adsorption onto SP and CSP at $\mathrm{pH} 4,7$, and 9.

\begin{tabular}{cccccccc}
\hline \multirow{2}{*}{ Model } & Parameter & \multicolumn{3}{c}{ SP } & \multicolumn{3}{c}{ CSP } \\
\cline { 3 - 7 } & & $\mathbf{p H ~ 4}$ & $\mathbf{p H ~ 7}$ & $\mathbf{p H ~ 9}$ & $\mathbf{p H ~ 4}$ & $\mathbf{p H ~ 7}$ & $\mathbf{p H ~ 9}$ \\
\hline \multirow{3}{*}{ Freundlich } & $K_{\mathrm{F}}\left(\mathrm{mmol}^{1-\mathrm{N}} \mathrm{L}^{\mathrm{N}} / \mathrm{kg}\right)$ & 4.072 & 1.432 & 1.277 & 1.602 & 1.051 & 0.416 \\
& $N(-)$ & 0.572 & 0.549 & 0.738 & 0.248 & 0.686 & 0.273 \\
& $\mathrm{R}^{2}$ & 0.899 & 0.762 & 0.860 & 0.790 & 0.899 & 0.611 \\
\hline \multirow{3}{*}{ Langmuir } & $q_{\mathrm{mL}}(\mathrm{mmol} / \mathrm{kg})$ & 1.838 & 0.672 & 0.605 & 0.957 & 0.455 & 0.249 \\
& $\mathrm{~b}(\mathrm{~L} / \mathrm{mmol})$ & 14.45 & 15.41 & 6.385 & 109.3 & 9.214 & 71.84 \\
& $\mathrm{R}^{2}$ & 0.900 & 0.776 & 0.878 & 0.811 & 0.934 & 0.705 \\
\hline \multirow{2}{*}{$\mathrm{DR}$} & $q_{\mathrm{mD}}\left(\mathrm{mmol}^{2} / \mathrm{kg}\right)$ & 1.883 & 0.706 & 0.521 & 1.111 & 0.450 & 0.287 \\
& $\beta\left(\mathrm{mol}{ }^{2} / \mathrm{kJ}^{2}\right), \times 10^{-2}$ & 1.569 & 1.563 & 2.229 & 0.610 & 2.031 & 0.728 \\
& $E(\mathrm{~kJ} / \mathrm{mol})$ & 5.646 & 5.656 & 4.736 & 9.056 & 4.962 & 8.287 \\
& $\mathrm{R}^{2}$ & 0.900 & 0.774 & 0.883 & 0.815 & 0.942 & 0.661 \\
\hline
\end{tabular}

Table 4. Isotherm model parameters for $\mathrm{Pb}$ adsorption onto SP and CSP at $\mathrm{pH} 3,4.5$, and 7.

\begin{tabular}{cccccccc}
\hline \multirow{2}{*}{ Model } & Parameter & \multicolumn{3}{c}{ SP } & \multicolumn{3}{c}{ CSP } \\
\cline { 3 - 7 } & & $\mathbf{p H ~ 3 ~}$ & $\mathbf{p H ~ 4 . 5}$ & $\mathbf{p H ~ 7}$ & $\mathbf{p H ~ 3}$ & $\mathbf{p H ~ 4 . 5}$ & $\mathbf{p H ~ 7}$ \\
\hline \multirow{3}{*}{ Freundlich } & $K_{\mathrm{F}}\left(\mathrm{mmol}^{1-\mathrm{N}} \mathrm{L}^{\mathrm{N}} / \mathrm{kg}\right)$ & 5.540 & 21.73 & 33.59 & 8.777 & 20.11 & 35.67 \\
& $N(-)$ & 0.431 & 0.281 & 0.221 & 0.266 & 0.370 & 0.222 \\
& $\mathrm{R}^{2}$ & 0.922 & 0.856 & 0.872 & 0.816 & 0.703 & 0.731 \\
\hline \multirow{3}{*}{ Langmuir } & $q_{\mathrm{mL}}(\mathrm{mmol} / \mathrm{kg})$ & 16.47 & 41.88 & 47.77 & 15.69 & 52.18 & 51.49 \\
& $\mathrm{~b}(\mathrm{~L} / \mathrm{mmol})$ & 0.466 & 1.037 & 5.833 & 1.358 & 0.529 & 4.040 \\
& $\mathrm{R}^{2}$ & 0.923 & 0.805 & 0.928 & 0.700 & 0.779 & 0.659 \\
\hline \multirow{2}{*}{$\mathrm{DR}$} & $q_{\mathrm{mD}}(\mathrm{mmol} / \mathrm{kg})$ & 12.27 & 35.86 & 45.96 & 13.69 & 41.76 & 47.31 \\
& $\left.\beta\left(\mathrm{mol}{ }^{2} / \mathrm{kJ}\right)^{2}\right), \times 10^{-2}$ & 28.85 & 13.10 & 2.802 & 10.36 & 37.18 & 2.666 \\
& $E(\mathrm{~kJ} / \mathrm{mol})$ & 1.317 & 1.953 & 4.224 & 2.197 & 1.160 & 4.330 \\
& $\mathrm{R}^{2}$ & 0.788 & 0.678 & 0.926 & 0.569 & 0.783 & 0.601 \\
\hline
\end{tabular}

The isotherm parameters affected by $\mathrm{pH}$ can be identified in Tables 3 and $4 . K_{\mathrm{F}}$ in the Freundlich model, $q_{\mathrm{mL}}$ in the Langmuir model, and $q_{\mathrm{mD}}$ in the DR model were affected by $\mathrm{pH} . K_{\mathrm{F}}, q_{\mathrm{mL}}$, and $q_{\mathrm{mD}}$ decreased in the case of As adsorption as $\mathrm{pH}$ increased but increased in the case of $\mathrm{Pb}$ adsorption. This indicates that the adsorption affinity, $K_{\mathrm{F}}$, and the maximum capacity $\left(q_{\mathrm{mL}}\right.$ and $\left.q_{\mathrm{mD}}\right)$ of SP and CSP decreased with $\mathrm{pH}$ in the case of As adsorption but increased with $\mathrm{pH}$ in the case of $\mathrm{Pb}$ adsorption. However, $N$ in the Freundlich model, $b$ in the Langmuir model, and $\beta$ and $E$ in the DR model varied irregularly regardless of $\mathrm{pH}$.

Figure 6a shows the linear relationship $\left(\mathrm{R}^{2}=0.990\right)$ between $q_{\mathrm{mL}}$ in the Langmuir model and $q_{\mathrm{mD}}$ in the DR model for As and $\mathrm{Pb}$ adsorption. This means that the maximum amounts of As and $\mathrm{Pb}$ adsorption were very similar even though the adsorption mechanisms of the Langmuir and DR models differed. Theoretically, $b$ in the Langmuir model is known to be related to the adsorption energy [28,29]. The relationship between $\ln b$ in the Langmuir model and $E$ calculated from the DR model was plotted in Figure $6 \mathrm{~b}$, and $b$ turned out to be very close to $E$ with high $\mathrm{R}^{2}(0.9897)$.

From the result of Figure 6b, Equations (7)-(9) were used to determine Gibb's free energy with ln $b$ for As and $\mathrm{Pb}$ adsorptions onto SP and CSP at several temperatures (293, 303, and $313 \mathrm{~K})$. Plotting $1 / \mathrm{T}$ and $\ln b$ for As and $\mathrm{Pb}$ onto SP and CSP shows good linear regression with a positive slope (Figure 7). The values of $\Delta \mathrm{G}^{\circ}, \Delta \mathrm{H}^{\circ}$, and $\Delta \mathrm{S}^{\circ}$ are summarized in Table 5 . The negative values of $\Delta \mathrm{G}^{\circ}$ indicate that the $\mathrm{As}$ and $\mathrm{Pb}$ adsorption process was spontaneous and favorable with increasing temperature [30]. The negative values of $\Delta \mathrm{H}^{\circ}$ show that the adsorption process was exothermic for As and $\mathrm{Pb}$ adsorption onto SP and CSP. However, the $\Delta \mathrm{S}^{\circ}$ value was positive for As adsorption onto SP and CSP, which denotes increased randomness during adsorption but negative randomness for $\mathrm{Pb}$ adsorption, which indicates decreased randomness. 

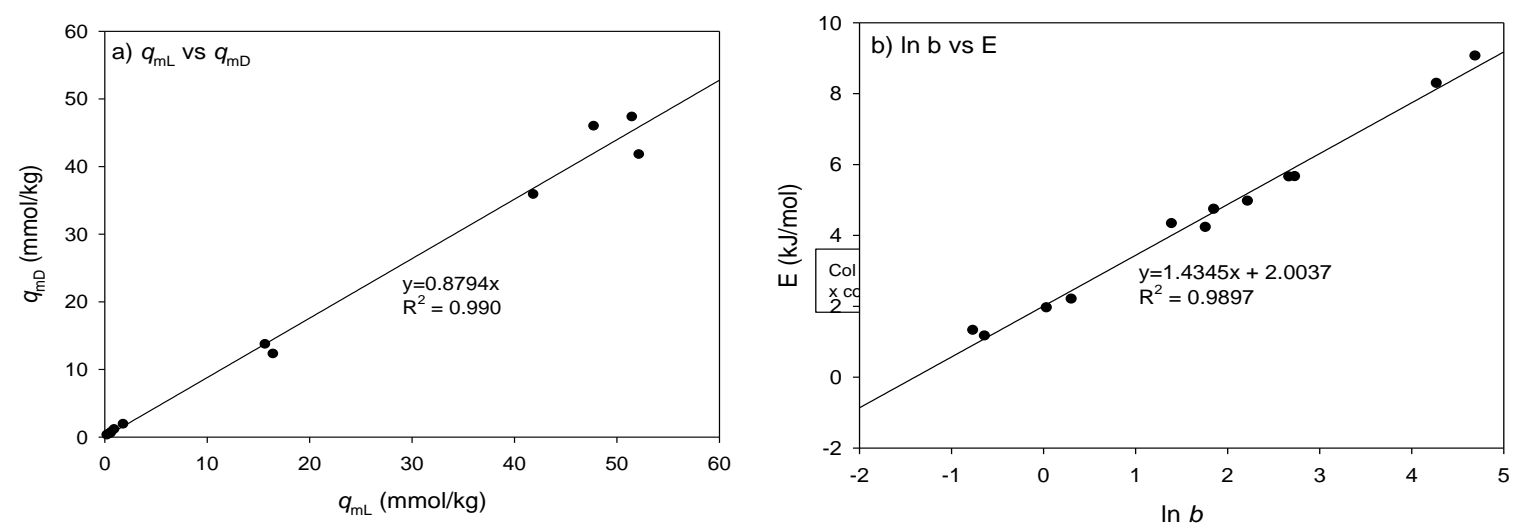

Figure 6. Relationship between (a) $q_{\mathrm{mL}}$ and $q_{\mathrm{mD}}$, and (b) $\ln b$ and $E$.
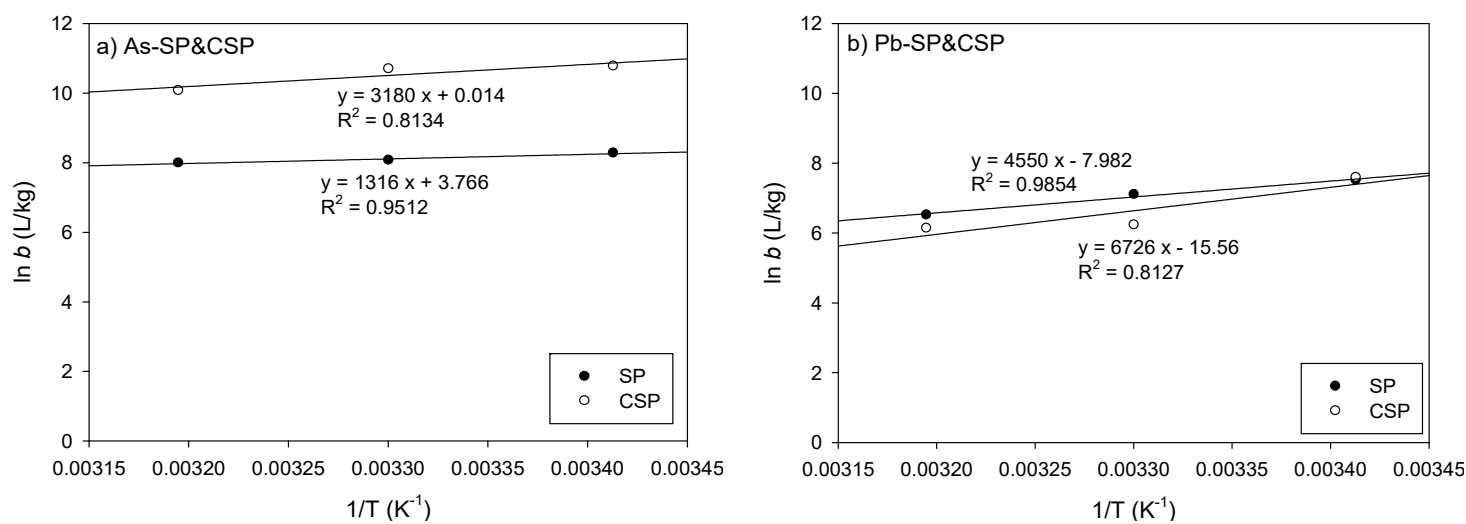

Figure 7. Relationship between $1 / \mathrm{T}$ and $\ln b$ for (a) As and (b) $\mathrm{Pb}$.

Table 5. Results of thermodynamic analyses for $\mathrm{As}$ and $\mathrm{Pb}$ adsorption at 293, 303, and $313 \mathrm{~K}$.

\begin{tabular}{cccccccc}
\hline \multirow{2}{*}{ Material } & Parameter & \multicolumn{3}{c}{ SP } & \multicolumn{3}{c}{ CSP } \\
\cline { 3 - 7 } & & $\mathbf{2 9 3 ^ { \circ } \mathbf { K }}$ & $\mathbf{3 0 3}^{\circ} \mathbf{K}$ & $\mathbf{3 1 3}^{\circ} \mathbf{K}$ & $\mathbf{2 9 3}^{\circ} \mathbf{K}$ & $\mathbf{3 0 3}^{\circ} \mathbf{K}$ & $\mathbf{3 1 3}^{\circ} \mathbf{~ K}$ \\
\hline \multirow{3}{*}{$\mathrm{ln} b$} & 8.276 & 8.073 & 7.991 & 10.78 & 10.70 & 10.08 \\
& $b$-based $\Delta \mathrm{G}^{\circ}(\mathrm{kJ} / \mathrm{mol})$ & -20.16 & -20.34 & -20.79 & -26.25 & -26.96 & -26.22 \\
& $b$-based $\Delta \mathrm{S}^{\circ}(\mathrm{kJ} / \mathrm{mol} / \mathrm{K})$ & & 0.0313 & & & 0.00012 & \\
& $b$-based $\Delta \mathrm{H}^{\circ}(\mathrm{kJ} / \mathrm{mol})$ & & -10.94 & & & -26.44 & \\
\hline \multirow{3}{*}{$\mathrm{Pb}$} & $\ln b$ & 7.513 & 7.104 & 6.518 & 7.592 & 6.232 & 6.139 \\
& $b$-based $\Delta \mathrm{G}^{\circ}(\mathrm{kJ} / \mathrm{mol})$ & -18.30 & -17.90 & -16.96 & -18.50 & -15.70 & -15.98 \\
& $b$-based $\Delta \mathrm{S}^{\circ}(\mathrm{kJ} / \mathrm{mol} / \mathrm{K})$ & & -0.0664 & & & -0.1294 & \\
& $b$-based $\Delta \mathrm{H}^{\circ}(\mathrm{kJ} / \mathrm{mol})$ & & -37.83 & & & -55.92 & \\
\hline
\end{tabular}

\section{Conclusions}

The adsorptive removal of $\mathrm{As}$ and $\mathrm{Pb}$ was successfully conducted using SP and CSP in this study. $\mathrm{As}$ and $\mathrm{Pb}$ could be adsorbed onto both $\mathrm{SP}$ and $\mathrm{CSP}$, but $\mathrm{Pb}$ adsorption was more favorable for both adsorbents. The maximum amount of $\mathrm{Pb}$ adsorption was higher than that of As because chitosan has some functional groups (amine and hydroxyl groups) that are favorable to metal adsorption. The $\mathrm{pH}$ was also a major factor affecting the adsorption of $\mathrm{As}$ and $\mathrm{Pb}$. The adsorbed amount of As decreased as the $\mathrm{pH}$ increased, whereas that of $\mathrm{Pb}$ increased. Therefore, the $\mathrm{pH}$ should be adjusted according to the target material of concern. The results of thermodynamic analyses indicated that the adsorption of As and $\mathrm{Pb}$ onto $\mathrm{SP}$ and $\mathrm{CSP}$ with negative $\Delta \mathrm{G}^{\circ}$ values was spontaneous.

Author Contributions: Conceptualization, S.O. and K.J.; methodology, S.O., K.J., G.-H.S., and H.B.; software, S.O.; formal analysis, S.O. and H.-T.K.; data curation, S.O. and H.B.; writing-original draft preparation, S.O.; writing-review and editing, S.O. and H.-T.K. 
Funding: This research was supported by the Kyungpook National University Fund, 2017.

Acknowledgments: The authors are grateful to Kyungpook National University for supporting this research.

Conflicts of Interest: The authors declare no conflict of interest.

\section{References}

1. Jain, C.K.; Singh, R.D. Technological options for the removal of arsenic with special reference to South East Asia. J. Environ. Manag. 2012, 107, 1-18. [CrossRef] [PubMed]

2. Jiang, J.Q.; Ashekuzzaman, S.M.; Jiang, A.; Shrifuzzaman, S.M.; Chowdhury, S.R. Arsenic contaminated groundwater and its treatment options in Bangladesh. Int. J. Environ. Res. Public Health 2013, 10, $18-46$. [CrossRef] [PubMed]

3. Clausen, J.L.; Bostick, B.; Korte, N. Migration of lead in surface water, pore water, and groundwater with a focus on firing ranges. Crit. Rev. Environ. Sci. Technol. 2011, 41, 1397-1448. [CrossRef]

4. Zhu, J.; Lou, Z.; Liu, Y.; Fu, R.; Baig, S.A.; Xu, X. Adsorption behavior and removal mechanism of arsenic on graphene modified by iron-manganese binary oxide (FeMnOx/RGO) from aqueous solutions. RSC Adv. 2015, 5, 67951-67961. [CrossRef]

5. Phan, K.; Sthiannopkao, S.; Kim, K.Y.; Wong, M.H.; Sao, V.; Hashim, J.H.; Yasin, M.S.M.; Aljunid, S.M. Health risk assessment of inorganic arsenic intake of Cambodia residents through groundwater drinking pathway. Water Res. 2010, 44, 5777-5788. [CrossRef] [PubMed]

6. Choi, S.J.; Jun, S.S.; Oh, J.E.; Monteiro, P.J.M. Properties of alkali-activated systems with stone powder sludge. J. Mater. Cycles Waste Manag. 2010, 12, 275-282. [CrossRef]

7. Kim, J.M.; Jeong, J.Y.; Choi, S.J.; Kim, B.J. The density and strength properties of light weight foamed concrete using stone-powder sludge in hydrothermal reaction condition. J. Korea Concr. Inst. 2006, 18, 687-693.

8. Al-Jabari, M. Kinetics mass transfer adsorption model for treating dairy wastewater with stone cutting solid waste. Environ. Technol. Innov. 2017, 7, 21-29. [CrossRef]

9. Hasan, S.; Krishnaiah, A.; Ghosh, T.K.; Viswanath, D.S.; Boddu, V.M.; Smith, E.D. Adsorption of chromium(VI) on chitosan-coated perlite. Sep. Sci. Technol. 2003, 38, 3775-3793. [CrossRef]

10. Qi, L.; Xu, Z. Lead sorption from aqueous solutions on chitosan nanoparticles. Colloids Surf. A Physicochem. Eng. Asp. 2004, 251, 183-190. [CrossRef]

11. Gupta, A.; Yunus, M.; Sankararamakrishnan, N. Chitosan- and iron-chitosan-coated sand filters: A cost-effective approach for enhanced arsenic removal. Ind. Eng. Chem. Res. 2013, 52, 2066-2072. [CrossRef]

12. Cho, D.W.; Jeon, B.H.; Chon, C.M.; Schwartz, F.W.; Jeong, Y.; Song, H. Magnetic chitosan composite for adsorption of cationic and anionic dyes in aqueous solution. J. Ind. Eng. Chem. 2015, 28, 60-66. [CrossRef]

13. Sparks, D.L.; Page, A.I.; Helmke, P.A.; Loeppert, R.H.; Soltanpour, P.N.; Tabatabai, M.A.; Johnston, C.T.; Sumner, M.E. Methods of Soil Analysis Part 3 Chemical Methods, 1st ed.; Soil Science Society of America, Inc.; American Society of Agronomy, Inc.: Madison, WI, USA, 1996; pp. 1244-1248.

14. Niazi, N.K.; Burton, E.D. Arsenic sorption to nanoparticulate mackinawite (FeS): An examination of phosphate competition. Environ. Pollut. 2016, 218, 111-117. [CrossRef] [PubMed]

15. Oh, S.; Kwak, M.Y.; Shin, W.S. Competitive sorption of lead and cadmium onto sediments. Chem. Eng. J. 2009, 152, 376-388. [CrossRef]

16. Farrell, J.; Relnhard, M. Descorption of halogenated organics from model solids, sediments, and soil under unsaturated conditions. 1. Isotherms. Environ. Sci. Technol. 1994, 28, 53-62. [CrossRef] [PubMed]

17. Dada, A.O.; Olalekan, A.P.; Olatunya, A.M.; DaDa, O. Langmuir, Freundlich, Temkin and Dubinin-Radushkevich isotherms studies of equilibrium sorption of $\mathrm{Zn}^{2+}$ onto phosphoric acid modified rice husk. IOSR J. Appl. Chem. 2012, 3, 38-45.

18. Horsfall, M.; Spiff, A.I.; Abia, A.A. Studies on the influence of mercaptoacetic acid (MAA) modification of cassava (manihot sculenta cranz) waste biomass on the adsorption of $\mathrm{Cu}^{2+}$ and $\mathrm{Cd}^{2+}$ from aqueous solution. Korean Chem. Soc. 2004, 25, 969-976.

19. Kundu, S.; Gupta, A.K. Arsenic adsorption onto iron oxide-coated cement (IOCC): Regression analysis of equilibrium data with several isotherm models and their optimization. Chem. Eng. J. 2006, 122, 93-106. [CrossRef] 
20. Liu, Y. Is the free energy change of adsorption correctly calculated? J. Chem. Eng. Data 2009, 54, 1981-1985. [CrossRef]

21. He, J.; Hong, S.; Zhang, L.; Gan, F.; Ho, Y.S. Equilibrium and thermodynamic parameters of adsorption of methylene blue onto rectorite. Fresenius Environ. Bull. 2010, 19, 2651-2656.

22. Chisholm, J. Comparison of quartz standards for X-ray diffraction analysis: HSE A9950 (Skiron F600) and NIST SRM 1878. Ann. Occup. Hyg. 2005, 49, 351-358. [PubMed]

23. Appel, C.; Ma, L.Q.; Rhue, R.D.; Kennelley, E. Point of zero charge determination in soils and minerals via traditional methods and detection of electroacoustic mobility. Geoderma 2003, 113, 77-93. [CrossRef]

24. Anto, S.M.; Annadurai, G. Arsenic adsorption from aqueous solution using chitosan nanoparticle. Res. J. Nanosci. Nanotechnol. 2012, 2, 31-45.

25. Hamed, I.; Ozogul, F.; Regenstein, J.M. Industrial application of crustacean by-products (chitin, chitosan, and chitoloigosaccharides): A review. Trends Food Sci. Technol. 2016, 48, 40-50. [CrossRef]

26. Zhang, L.; Zeng, Y.; Cheng, Z. Removal of heavy metal ions using chitosan and modified chitosan: A review. J. Mol. Liquids. 2016, 214, 175-191. [CrossRef]

27. Suteu, D.; Bilba, D.; Dan, F. Synthesis and characterization of polyamide powders for sorption of reactive dyes from aqueous solutions. J. Appl. Polym. Sci. 2007, 105, 1833-1843. [CrossRef]

28. Kamau, J.; Kamau, G. Modeling of experimental adsorption isotherm data for chlorothalonil by Nairobi river sediment. Mod. Chem. Appl. 2017, 5, 1-7.

29. Ayawei, N.; Ebelegi, A.N.; Wankasi, D. Modelling and interpretation of adsorption isotherms. J. Chem. 2017, 2017, 3039817. [CrossRef]

30. Khelaifia, F.Z.; Hazourli, S.; Nouacer, S.; Rahima, H. Valorization of raw biomaterial waste-date stones-for $\mathrm{Cr}$ (VI) adsorption in aqueous solution: Thermodynamics, kinetics and regeneration studies. Int. Biodeterior. Biodegrad. 2016, 114, 76-86. [CrossRef]

(C) 2019 by the authors. Licensee MDPI, Basel, Switzerland. This article is an open access article distributed under the terms and conditions of the Creative Commons Attribution (CC BY) license (http://creativecommons.org/licenses/by/4.0/). 